\title{
PENINGKATAN PERKEMBANGAN SOSIAL MELALUI PETAK BENTENG USIA 5-6 TAHUN TK CITA SAHABAT MULIA PONTIANAK
}

\author{
Mardiyanti, Muhamad Ali, Dian Miranda \\ Program Studi Pendidikan Guru Pendidikan Anak Usia Dini FKIP Untan Pontianak \\ Email: yanti11ptk@gmail.com
}

\begin{abstract}
This research is motivated by a lack of social development in children aged 5-6 years in a class of 12 people with 2 teachers. This study aims to improve children's social development through playing petak benteng game in 5-6 year olds at Cita Sahabat Mulia Kindergarten, Pontianak. Good social development is very important for every child to be able to interact and be accepted in their social environment, therefore it is necessary to improve children's social development from an early age. This research is a Classroom Action Research. The subjects in this study were 5-6 years old at TK Cita Sahabat Mulia Pontianak. This research variable is the social development of children. Data collection through observation and interviews. The data analysis technique was carried out descriptively. The stages of this research consisted of planning, implementing, observing and reflecting. This research was conducted in 2 cycles. The results showed that the social development of children can improve after the action. The action taken is playing the petak benteng. The social development of the child develops in the aspect of the child being able to cooperate with friends reaching 100\%, the aspect of the child being able to respect others up to $100 \%$, and the aspect of the child being able to obey the agreed rules reaching $92 \%$ in the second cycle of meeting 2.Thus the child's social development can be improved through play petak benteng activities.
\end{abstract}

\section{Keywords: Social Development, Method of Petak Benteng Game}

\section{PENDAHULUAN}

Anak adalah anugrah yang dititipkan Allah SWT kepada setiap pasangan dan pasangan itu menjadi orangtuanya. Memiliki anak yang sehat baik jasmani maupun rohani adalah dambaan setiap orangtua. Sudah menjadi kodrat manusia yang terlahir di dunia ini sebagai makhluk sosial, tidak dapat hidup sendiri dan membutuhkan orang lain untuk bersama-sama hidup tumbuh di dunia ini. Interaksi sosial yang pertama didapatkan adalah dari lingkungan keluarga inti yaitu orangtua dan saudara dengan berjalannya waktu perkembangan sosial mulai kompleks ketika anak menginjak usia 3 tahun dimana anak mulai memasuki ranah pendidikan diluar rumah. Anak sudah mulai bermain bersama teman sebaya, memasuki usia 4-6 tahun perkembangan sosial sudah mulai berjalan, hal ini tampak dari kemampuan mereka dalam melakukan kegiatan secara berkelompok dan kegiatan bersama berbentuk dari sebuah permainan.

Untuk mewujudkan perkembangan sosial yang sehat adalah dengan metode bermain. Pembelajaran yang dilakukan dengan teknik permainan pada anak usia dini akan lebih santai, mudah dan menyenangkan, anak mengikuti permainan dengan tanpa beban menikmati waktu bersama teman seusianya. Hurlock mengungkapkan bahwa bermain 
dapat diartikan sebagai kegiatan yang dilakukan untuk kesenangan yang ditimbulkannya, tanpa mempertimbangkan hasil akhir (dalam Hurlock,1978) Bermain memberikan kesempatan pada anak untuk mengekspresikan dorongan kreatifnya, merasakan obyek-obyek dan tangan untuk menemukan sesuatu dengan cara yang baru serta mengartikannya dalam berbagai alternatif. Bermain memberikan kesempatan anak untuk berfikir dan bertindak imajinatif, serta penuh daya khayal yang erat hubungannya dengan perkembangan kreatifitas dan jiwa sosial anak. Bentuk permainan yang dapat mengembangkan jiwa sosial dalam kegiatan fisik motorik yang dilakukan secara berkelompok atau beregu baik menggunakan alat atau tidak dalam permainan.

Permainan modern sangat diminati saat ini karena pengaruh teknologi dan globalisasi namun pengaruh negatif yang perlu diwaspadai seperti bermain tanpa pendampingan, anak menjadi pasif, individual. Saat ini permainan tradisional semakin jauh dari dunia pendidikan anak dan kehidupan sosial dalam masyarakat, karena banyaknya permainan-permainan modern yang menarik dan mengasyikkan. Materi proses dan fungsi permainan tradisional merupkan media yang tepat untuk belajar. Anak dapat bermain dengan ceria, setelah permainan usai, tanpa disadari ada pengetahuan yang mereka dapatkan. Permainan tradisional memberikan pelajaran kepada anak mengenai pentingnya menjaga lingkungan, menghormati sesama, hingga cinta kepada Tuhan, selain itu juga dekat dengan alam, sehingga dapat memberikan konstribusi dalam meningkatkan kecerdasan natural anak, serta pengembangan pribadi anak, aturan permainan dapat dibuat sendiri sehingga dapat melatih kreatifitas dan tanggung jawab anak. Dengan demikian permainan dapat meningkatkan perkembangan sosial anak. Permainan ini tidak dimanfaatkan lagi sebagai salah satu metode yang diajarkan di sekolah, termasuk di TK Cita Sahabat Mulia sehingga anak-anak jauh dari nilai budaya, individual untuk itu peneliti mencoba suatu pemikiran untuk lebih memperkenalkan siswa yaitu dengan permainan petak benteng.

Dari hasil observasi peneliti di TK Cita Sahabat Mulia Pontianak pada kelompok 5-6 tahun yang berjumlah 12 anak dan hanya 4 (33\%) anak yang perkembangan sosialnya sudah berkembang dengan baik, mereka dapat bekerjasama serta melaksanakan permainan sesuai dengan peraturan yang telah disepakati bersama, dan sikap saling menghargai antar sesama teman Dan 8 (67\%) anak masih membutuhkan bimbingan dalam menanamkan sikap bekerja sama dengan teman, sebagian anak belum dapat mentaati peraturan yang dibuat bersama, dan rendahnya sikap saling menghargai sesama teman, selain itu guru kurang mengenalkan dan mempraktekkan permainan petak benteng yang dapat meningkatkan perkembangan sosial anak. Permainan hanya dilakukan untuk mengisi waktu anak pulang. Masih ditemui beberapa anak yang cenderung senang dan memilih untuk bermain sendiri, tidak mau berinteraksi dan bersosialisasi dengan anak lain.

Berbagai ragam permainan yang dilakukan sangat bermanfaat untuk anak, baik untuk pertumbuhan, perkembangan maupun sebagai hiburan. Sebuah permainan yang dilakukan akan menyenangkan apabila permainan yang dilakukan bervariasi, seimbang dengan aturan bermain yang tidak kaku. Oleh karena itu metode bermain petak benteng akan penulis terapkan dengan menggunakan materi dan media yang sesuai untuk memperbaiki pembelajaran dalam upaya meningkatkan perkembangan sosial anak.

Novi Mulyani mengungkapkan bahwa permainan petak benteng atau biasa disebut bentengan atau jaga benteng adalahpermainan yang dimainkan oleh 2 grup, masing masing terdiri dari 4 sampai dengan 8anak atau lebih semakin banyak jumlahnya semakin seru permainan. Masing-masing grup memilih tempat sebagai benteng, biasanya pada sebuah tiang, batu atau pilar yang disebut benteng (Novi Mulyani, 2016 ). Permainan dapat dilakukan di lapangan atau halaman rumah, permainan ini biasanya diikuti oleh 4 
sampai 8 anak atau lebih semakin ramai jumlah kelompok maka permainan semakin bersemangat. Aturan permainan disesuaikan dengan kesepakatan bersama termasuk dalam menentukan lokasi dan benteng masingmasing kelompok. Andarini mengungkapkan bahwa permainan petak benteng ini berkelompok yang terbagi menjadi 2 tim yang masing masing tim menentukan bentengnya sebelum permainan dimulai (Andarini : 2010). Permainan petak benteng menjadi media anak untuk bersosialisasi karena dimainkan secara bersama-sama. Mulyani mengungkapkan bahwa permainan tradisional secara berkelompok dapat berpeluang

mengembangkan emosi dan sosial anak ini dapat di lihat dari komunikasi dan interaksi yang terjalin ketika mengikuti permainan, semua anak berperan secara aktif dalam mensukseskan permainan (Mulyani, 2016). Andarini mengungkapkan bahwa anak dapat menghargai orang lain dan aturan kalah menang dapat menjadi peluang untuk saling menghargai, permainan ini juga melatih kemampuan anak bekerjasama dalam menjaga benteng, memata-matai musuh, menangkap musuh dan menduduki benteng lawan (Andarini, 2010). Pemain harus menyesuaikan dengan kondisi kelompok, bisa berempati dengan kelebihan dan kekurangan teman maupun lawan mainnya. Permainan ini dapat melatih mengasah kemampuan dalam menyusun strategi dan meningkatkan kreatifitas agar kelompoknya dapat menjadi pemenang. Anak-anak berlatih untuk membangun sportifitas, para pemain harus mampu mentaati peraturan, sportif, dan menghargai kelompok lawan yang menang.

Berdasarkan hasil penelitian dan pembahasan yang telah dipaparkan pada bagian terdahulu, maka secara umum dapat disimpulkan bahwa melalui permainan petak benteng dapat meningkatkan perkembangan sosial pada anak usia 5-6 tahun di TK Cita Sahabat Mulia Pontianak terlihat dari hasil Perencanaan pembelajaran yang disiapkan oleh guru untuk meningkatkan perkembangan sosial pada anak usia 5-6 tahun di TK Cita Sahabat Mulia Pontianak sudah baik diperoleh skor rata-rata 3,6. Pelaksanaan pembelajaran melalui permainan petak benteng untuk meningkatkan perkembangan sosial anak usia 5-6 tahun di TK Cita Sahabat Mulia diperoleh skor 3,7 dengan kategori baik, hal ini menunjukkan guru memiliki kemampuan dalam melakukan pelaksanaan pembelajaran untuk meningkatkan perkembangan sosial anak melalui permainan petak benteng. Peningkatan perkembangan sosial anak setelah pembelajaran berkembang sesuai harapan (BSH) dengan persentase 97\% dengan permainann petak benteng pada anak usia 5 - 6 tahun di TK Cita Sahabat Mulia Pontianak.

\section{METODE PENELITIAN}

Penelitian ini menggunakan bentuk Penelitian Tindakan Kelas (PTK). Sugiyono (2013, p. 2) menyatakan metode penelitian pada dasarnya merupakan cara ilmiah untuk mendapatkan data dengan tujuan dan kegunaan tertentu. Adapun alasan untuk menggunakan PTK pada penelitian ini adalah untuk menjelaskan bagaimana denganbermain petak benteng dapat meningkatkan perkembangan sosial anak usia 5-6 tahun di TK Cita Sahabat Mulia Pontianak. Bentuk penelitian tindakan kelas untuk memperbaiki pembelajaran yang kurang berhasil Subjek dalam penelitian ini adalah 1 orang guru dan anak yang berjumlah 12 orang dalam satu kelas terdiri dari 3 orang anak laki-laki dan 9 anak perempuan.

Menurut Arikunto (2015, p. 164) pada satu siklus terdiri dari empat rangkaian kegiatan yaitu merencanakan,melaksanakan tindakan pembelajaran mengamati hasil dan proses pembelajaran dan merefleksikan guna perbaikan tindakan selanjutnya. Dapat ditarik kesimpulan bahwa dari empat kegiatan dapat mempermudah guru atau peneliti dalam suatu proses untuk mencapai suatu tindakan dalam kegiatan. Peneliti mengumpulkan data dengan tehnik observasi, wawancara dan dokumentasi. Untuk menjawab masalah perencanaan dan pelaksanaan kegaiatan pembelajaran untuk meningkatkan perkembangan sosial anak dan Wiraatmatmadja (2002, p.217) menyatakan analisis data adalah diartikan sebagai upaya mengolah data menjadi informasi, sehingga 
karakteristik atau sifat-sifat data tersebutdapat dengan mudah difahami dan bermanfaatuntuk menjawab masalah-masalah yang berkaitan dengan kegiatan penelitian . Dalam penelitian hasil observasi baik terhadap guru maupun anak dihitung dengan menggunakan rumus persentase menurut Iskandar (2011, p.12)

$\mathrm{P} \%=\mathrm{F} / \mathrm{N} \times 100$ Keterangan : $\mathrm{P}$ : persentasiF : Frekuensi jawaban $\mathrm{N}$ : Jumlah responden 100 Bilangan tetap. Kategori pencapaian setiap aspek yang dinilai yaitu (1) Berkembang sangat baik (BSB) anak melakukan kegiatan tanpa bantuan (2) Berkembang sesuai harapan (BSH) anak dapat melakukan kegiatan dengan sedikit arahan dari guru (3) Mulai Berkembnag (MB) Anak mulai dapat (BB) anak belum mampu melakukan kegiatan.

\section{HASIL PENELITIAN DAN \\ PEMBAHASAN \\ Hasil Penelitian}

\section{Perencanaan}

Perencanaan pada kegiatan siklus I sebanyak 2 kali pertemuan keduanya dilaksanakan pada hari Kamis 3 dan 17 Oktober 2019. Untuk siklus I pertemuan 1 tema Binatang dengan subtema permainan petak benteng. Adapun langkah yang dilakukan peneliti yaitu menyusun RPPH mencakup materi dan bahan ajar, menyetting tempat untuk permainan petak benteng yang akan dilaksanakan dan menyiapkan lembar obsevasi pada siklus I pertemuan 2 masih dengan tema binatang guru menjelaskan tentang aspek pentingnya bekerjasama, menghargai orang lain, dan mentaati aturan permainan. Untuk siklus 2 dilaksanakan 2 pertemuan. Pada siklus II pertemuan 1dilaksanakan pada hari Rabu 23 Oktobe 2019 dengan tema Binatang dan sub tema permainan petak benteng. Guru menyipakan RPPH dan menyeting tempat bermain serta bercakap-cakap tentang pentingnya bekerjasama, menghargai dan mentaati aturan.

\section{Pelaksanaan}

Pelaksanaan pada siklus I sesuai dengan RKH yang di buat. Pada siklus ini menitikberatkan kemampuan guru dalam pelaksanaan terhadap aspek pijakan setelah main yaitu penguasaan materi, efektifitas dalam mengajar, dan menutup kegiatan pembelajaran. Pada Siklus II Penilaian Kemampuan guru dititikberatkan pada aspek pijakan sebelum main diantaranya kemampuan guru mengajak anak berdoa dan mengucapkan salam, guru mengecek kehadiran anak, guru menanyakan hari tanggal, bulan dan tahun, Guru menyampaikan kegiatan yang akan dilaksanakan, serta guru menunjukkan sikap ramah dan penuh perhatian serta sikap bersahabat, terbuka dan penuh perhatian kepada anak.

\section{Observasi}

Pengamatan yang dilakukan terhadap aktifitas anak dengan mengisi lembar observasi dengan tanda checklist apakah pembelajaran yang dilakukan sudah sesuai dengan perangkat yang dibuat. Adapun indikator yang dijadikan sasaran dalam observasi tersebut adalah aspek anak dapat bekerja sama ketika bermain, anak dapat menghargai orang lain dalam bermain dan anak dapat mentaati aturan dalam bermain

\section{Refleksi}

Hasil yang diperoleh dari observasi dikumpulkan serta dianalisis dalam tahap ini. Dari hasil observasi guru dapar merefleksikan diri dengan melihat proses dan data observasi. Guru bersama rekan sejawat melakukan diskusi tentang temuan maupun masalahmasalah yang dirasakan oleh rekan sejawat guru kelas. Hasil ini dianalisa dan data dari tahap ini dijadikan acuan untuk merencanakan siklus berikutnya.

Pada siklus I perbaikan perencanaan pembelajaran masih pada skor rata-rata baik, pada poin aspek perumusan tujuan masih memerlukan perbaikan. pelaksanaan pembelajaran pada poin pijakan setelah main menjadi sasaran penilaian dan masih memerlukan perbaikan, sedangkan perkembangan sosial anak mengalami 
peningkatan, namun belum mencapai kategori "Berkembang Sesuai Harapan". Pada siklus II pertemuan perbaikan perencanaan pembelajaran dan perbaikan pelaksanaan pembelajaran sudah mencapai skor rata-rata cukup baik. Adapun perkembangan sosial anak mengalami peningkatan, dan sudah mencapai kategori "Berkembang Sesuai Harapan".

\section{Pembahasan}

Berdasarkan proses PTK yang telah dilaksanakan kemampuan guru dalam merencanakan pembelajaran pada siklus $1 \mathrm{ke}$ siklus II sudah terjadi perubahan yang memuaskan terutama pada aspek yang dinilai, pada siklus I pertemuan 1 perencanaan pembelajaran kinerja guru dalam aspek penilaian perkembangan sosial anak pada kategori cukup dengan skor 2,4 selajutnya pada pertemuan 2 perencanaan yang dibuat guru sudah mengalami peningkatan menjadi 2,8 pada pertemuan ke-2 dalam kategori baik, sehingga guru melanjutkan pada siklus ke II, untuk pertemuan 1 kinerja guru mengalami peningkatan skor menjadi 3 dengan kategori cukup baik, guru sudah dapat merencanakan pembelajaran dengan baik tapi masih sedikit memerlukan perbaikan dan pada siklus II pertemuan terakhir mencapai kategori "baik" dengan skor 3,6. Guru dinilai sudah dapat melaksanakan pembelajaran dengan sangat baik dan meningkatan pada aspek sosial yakni bekerja sama, saling menghargai dan mentaati aturan dalam permainan. Dengan demikian keberhasilan perbaikan perencanaan pembelajaran yang dilakukan oleh guru didukung oleh kemampuan guru itu sendiri dalam menentukan tema/sub tema sesuai, metode dan media yang tepat serta penilaian yang sesuai dengan tujuan yang akan dicapai dalam pembelajaran.

Berdasarkan proses PTK yang telah dilaksanakan kemampuan guru dalam pelaksanaan pembelajaran pada siklus I pertemuan 1 dan 2 mengalami peningkatan dari nilai rata-rata 2,6 menjadi 2,9 dengan kategori baik .Pada siklus ini masih ditemui kekurangan pada pijakan setelah main, dimana guru dianggap kurang memberikan motivasi untuk anak-anak yang kalah dalam bermain dan mengarahkan kepada anak yang menang untuk saling menghargai dan tidak mengolok-olok kelompok yang kalah dalam permainan, serta masih ditemui anak-anak yang belum mentaati aturan yang dibuat bersama misalnya tidak boleh menarik baju atau kerudung teman, tidak mendorong teman pada saat berlari, dan masih ditemui beberapa anak yang kebingungan dalam mempertahankan bentengnya.

Pelaksanaan dilanjutkan pada pertemuan siklus berikutnya yaitu siklus ke II pertemuan 1 pelaksanaan mengalami peningkatan menjadi rata-rata 3,2 dan pada pertemuan ke 2 pelaksanaan pembelajaran yang dilakukan guru semakin baik dengan nilai rata-rata 3,6 dengan kategori baik. Nana Sudjana (2010 : 136 ) Mengatakan bahwa pelaksanaan pembelajaran adalah proses yang diatur sedemikian rupa menurut langkah-langkah tertentu agar pelaksanaan mencapai hasil yang diharapkan. Selama proses pelaksanaan kegiatan bermain petak benteng anak anak sangat antusias dalam bermain bersama kelompoknya. Anak-anak berusaha bekerja sama dalam menjaga benteng kelompoknya masing-masing, mereka bekerja sama berusaha untuk memegang benteng lawan dan bekerjasama dalam menyelamatkan apabila salah satu kelompoknya ada yang tertawan, anak-anak berusaha untuk mentaati aturan permainan yang dibuat bersama, dan komitmen dengan aturan yang telah disepakati. Selama proses pelaksanaan anak-anak juga terlihat untuk saling mneghargai ketika kelompoknya mengalami kekalahan dan berjiwa besar untuk menerima kekalahan. Dari hal ini pelaksanaan yang dilakukan oleh peneliti dinilai sangat baik oleh teman sejawat dikarenakan kemampuan yang dilakukan selama proses pelaksanaan sesuai dengan yang diharapkan. Dengan demikian keberhasilan perbaikan pelaksanaan pembelajaran yang dilakukan oleh guru didukung oleh kemampuan guru dalam melaksanakan pembelajaran sesuai perencanaan dengan memperhatikan indikator yang menjadi sasaran penilaian dalam pelaksanaan. 
Peningkatan perkembangan sosial anak melalui metode permainan petak benteng pada anak usia 5-6 tahun dengan indikator yang dinilai yaitu anak dapat bekerja sama ketika bermain, anak dapat menghargai orang lain dalam bermain dan anak dapat mentaati peraturan yang berlaku dalam permainan sejalan dengan yang ditulis Andarini bahwa anak dapat menghargai orang lain dan aturan kalah menang dapat menjadi peluang untuk saling menghargai, permainan ini juga melatih kemampuan anak bekerjasama dalam menjaga benteng, memata-matai musuh, menangkap musuh dan menduduki benteng lawan (Andarini $2010: 18$ ).

Pada permainan ini yang dilakukansiklus I pertemuan 1 peneliti membagi anak menjadi 2 kelompok dengan cara mengelompokkan anak yang tidak lincah dalam berlari dengan anak yang agak pendiam, masing masing kelompok terdiri dari anak yang laju dalam berlari dan lambat dalam berlari dalam jumlah yang seimbang namun untuk pertemuan berikutnya setelah mereka mengetahui cara bermain serta melatih sportifitas dalam kelompok, pemilihan kelompok dilakukan dengan "hompimpa", dengan mencari pasanganmelalui sisi permukaan tangan atau telapak tangan setelah mendapatkan contoh dan arahan dalam bermain maka permainan dapat dilaksanakan. Pada siklus I di awal penelitian,peneliti hanya menemukan 17\% (2 anak ) saja anak yang mau bekerja sama, namun pada pertemuan selanjutnya 58\% (7 anak), dan meningkat lagi menjadi $67 \%$ (8 anak) dan pertemuan berikutnya peneliti mendapatkan hasil $100 \%$ dimana anak berkembang sesuai harapan maka pada siklus II pertemuaan ke 2 ini peneliti merasa cukup dan sudah mendapatkan hasil yang maksimal yaitu anakdapat bekerjasama dalam bermain petak benteng. Untuk sikap saling menghargai peneliti juga mendapatkan hasil yang memuaskan dimana pada awalnya hanya $33 \%$ (4 anak) saja anak yang memiliki sikap saling menghargai, kemudian dilakukan penelitian pada permainan berikutnya meningkat menjadi 58\% (7anak) dan dilanjutkan menjadi 83\% (10 anak) dan pada siklus berikutnya
$100 \%$ ( 12 anak) yang akhirnya mencapai dimana anak sudah dapat menunjukkan sikap saling menghargai sesama teman. Untuk sikap taat pada aturan permainan peneliti menemukan diawal pertemuan hanya $17 \%$ (2 anak) saja anak yang mentati aturan setelah dilakukan permainan petak benteng dan mendapatkan araha-arahan dari guru sikap anak-anak ini meningkat menjadi $42 \%$ (5 anak) dan pada pertemuan berikutnya menjadi 75\% (9 anak) dan hasil akhir yang dilakukan peneliti pada siklus II pertemuan ke 2 mencapai 92\% (11 anak) dengan kategori anak berkembang sesuai harapan sehingga dari pemaparan diatas dapat diambil kesimpulan rata-rata peningkatan perkembangan sosial yang terjadi anak berkembang sesuai harapan dan nilai rata-rata mencapai $97 \%$. Pada persentase inilah peneliti merasa peningkatan perkembangan sosial terhadap anak usia 5-6 tahun di TK Cita Sahabat Mulia sudah meningkat. Seafeldt dan Barbour (1994: 57-59) menyatakan, "keterampilan sosial meliputi: keterampilan komunikasi, berbagi (sharing), bekerja sama, dan berpartisipasi dalam kelompok masyarakat". Sejalan dengan inipermendiknas no 137 tahun 2014 menyatakan bahwa indikator tentang perkembangan sosial diantaranya adalah bersikap kooperatif dengan teman, mentaati aturan yang berlaku dalam sebuah permainan dan menghargai orang lain. Secara umum hasil penelitian ini menunjukkan bahwa permainan petak benteng efektif meningkatkan perkembangan sosial anak usia 5-6 tahun di TK Cita Sahabat Mulia.

\section{SIMPULAN DAN SARAN}

\section{Simpulan}

Berdasarkan hasil penelitian yang dilakukan maka dapat disimpulkan bahwa melalui permainan petak benteng dapat meningkatkan perkembangan sosial pada anak usia 5-6 tahun di TK Cita Sahabat Mulia Pontianak. Kesimpulan penelitian dapat diuraikan sebagai berikut: Perencanaan pembelajaran yang disiapkan oleh untuk meningkatkan perkembangan sosial pada anak usia 5-6 tahun di TK Cita Sahabat Mulia 
Pontianak diperoleh skor rata-rata 3,6.Dengan demikian guru dapat merencanakan pembelajaran dengan sangat baik melalui metode permaianan petak benteng untuk meningkatkan perkembangan sosial pada anak usia 5-6 tahun di TK Cita Sahabat Mulia Pontianak.

Pelaksanaan pembelajaran melalui permainan petak benteng untuk meningkatkan perkembangan sosial anak usia 5-6 tahun di TK Cita Sahabat Mulia diperoleh skor 3,6 dengan kategori baik, hal ini menunjukkan guru memiliki kemampuan dalam melakukan pelaksanaan pembelajaran untuk meningkatkan perkembangan sosial anak melalui permainan petak benteng. Peningkatan perkembangan sosial anak setelah pembelajaran dengan permainan petak benteng pada anak usia 5 - 6 tahun di TK Cita Sahabat Mulia Pontianak mengalami peningkatan yang cukup baik, peningkatan ini ditunjukkan dengan kemampuan anak berkembang sesuai harapan pada aspek anak dapat bekerja sama dengan teman, sikap saling menghargai .

\section{Saran}

Berdasarkan kesimpulan yang sudah peneliti paparkan diatas, maka peneliti memberikan saran diantaranya yaitu permainan petak benteng yang telah dilaksanakan terbukti mampu meningkatkan perkembangan sosial anak, karena itu guru dapat meningkatkan mutu pembelajaran dengan menggunakan cara yang dapatmenarik minat anak, menyenangkan sehingga tanpa disadari melatih sikap sosial.

Guru harus kreatif dalam mengajak anak bermain bersama untuk mewujudkan sikap sosial yang dimiliki oleh setiap anak dalam kehidupan sehari-hari sehingga setiap anak mempunyai kepribadian dalam sikap sosial yang dapat diterima dilingkungan masyarakat sebagai proses kehidupannya kelak.

\section{DAFTAR PUSTAKA}

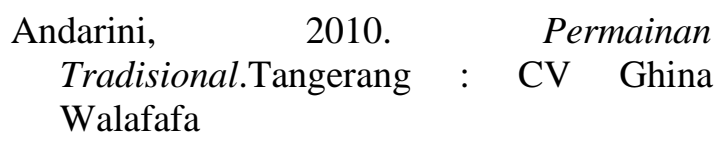

Elizabeth B. Hurlock, 1978. Perkembangan Anak. Jakarta : Penerbit Erlangga

Novi Mulyani.(2016). Dasar-dasar Pendidikan anak Usia Dini. Jogjakarta Kalmedia

Peraturan Mentri Pendidikan dan $\begin{array}{lll}\text { Kebudayaan } & \text { RI No.137 }\end{array}$ TentangStandar TPPA (2014). Jakarta.

Seefeld, Nita Babour.(1994). Early chilhood Education. New York : Mac Millan Publishing company.

Suharsimi Arikunto, Suharjono, dan Supardi,2015. Penelitian Tindakan Kelas. Jakarta: Bumi Aksara.

Sugiyono , (2013). Metode Penelitian Kuantitatif, Kualitatif, dan $R \& D$. Bandung: Alfabeta.

Uno Hamzah B. (2011). Menjadi peneliti PTK yang profesional. Bandung : Bumi Aksara 